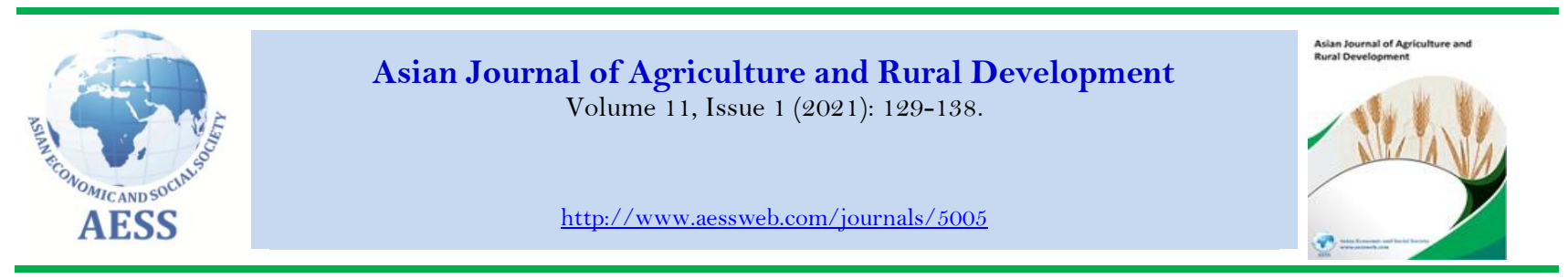

\title{
ENHANCING MARKET ORIENTATION OF COCOA FARMERS THROUGH FARMER BUSINESS SCHOOLS: THE GHANA COCOBOD EXPERIENCE
}

\begin{tabular}{l} 
ID Enoch Kwame Tham- \\
Agyekum $^{\text {a }}$ \\
iD Ernest Laryea Okorley \\
iD Joseph Kwarteng \\
iD John-Eudes Andivi Bakang \\
iD Fred Nimohe \\
\hline Article History \\
Received: 12 January 2021 \\
Revised: 24 February 2021 \\
Accepted: 8 March 2021 \\
Published: 25 March 2021 \\
Keywords \\
Cocoa farmers \\
Competition \\
Customer emphasis \\
COCOBOD \\
Farmer business school \\
Ghana \\
Intelligence generation \\
Intelligence dissemination \\
Market orientation \\
Market responsiveness.
\end{tabular}

\author{
a,de Department of Agricultural Economics, Agribusiness and Extension, Kwame Nkrumah \\ University of Science and Technology-Kumasi, Ghana. \\ ${ }^{b, c}$ Department of Agricultural Economics and Extension, University of Cape Coast-Cape \\ Coast, Ghana.
}

ه

\begin{abstract}
The study sought to ascertain how the Farmer Business School (FBS) introduced in 2012 by the Ghana Cocoa Board as an extension approach makes the Ghanaian cocoa farmer more business and entrepreneurially minded. The research methods included using the descriptive survey and multi-stage sampling techniques to cover the six cocoa regions and 600 cocoa farmers. The 600 cocoa farmers selected were made up of 230 non-participants and 370 participants of the FBS. In terms of competency, the results showed that FBS participants had greater knowledge, a more positive attitude, and better skills than non-participants. In terms of market orientation, FBS participants were more competitor oriented, had less intelligence generation, were less market responsive, had less intelligence dissemination, had more customer emphasis, and had more interfunctional coordination than non-participants. The market orientation of cocoa farmers can be enhanced by provision of relevant practical experience for attitudinal change.
\end{abstract}

\begin{abstract}
Contribution/Originality: This novel study investigated how the market orientation of cocoa farmers in Ghana can be enhanced through the Farmer Business School. The paper's primary contribution is finding that market orientation has a significant association with the attitudes and skills of FBS participant cocoa farmers.
\end{abstract}

DOI: 10.18488/journal.ajard.2021.111.129.138

ISSN(P): 2304-1455/ ISSN(E): 2224-4433

How to cite: Enoch Kwame Tham-Agyekum --- Ernest Laryea Okorley --- Joseph Kwarteng --- John-Eudes Andivi Bakang --- Fred Nimoh (2021). Enhancing Market Orientation of Cocoa Farmers through Farmer Business Schools: The Ghana Cocobod Experience. Asian Journal of Agriculture and Rural Development, 11(1), 129-138. 10.18488/journal.ajard.2021.111.129.138 (C) 2021 Asian Economic and Social Society. All rights reserved.

\section{INTRODUCTION}

The cocoa industry in Ghana is characterized by low productivity and peasantry, although it remains a major contributor to the national economy (Gockowski, Afari-Sefa, Sarpong, Osei-Asare, \& Dziwornu, 2011; ObuobisaDarko, 2015). In the past, extension organizations have been more concerned with the process of disseminating technical information or innovations about the production needs of farmers. This extension strategy over the years has improved cocoa yields marginally but its impacts have not been sustainable (GIZ, 2015; Wiredu, Mensah-Bonsu, Andah, \& Fosu, 2011). Röling (2009) reported that in sub-Saharan Africa, the majority of smallholder farmers rarely applied the technical innovations received from the extension system, which in part, may explain why yields are low. 
The Cocoa Research Institute of Ghana (CRIG) had reported that only 3\% of cocoa farmers in Ghana had adopted the full range of CRIG-recommended production technologies, leading to yield and production levels below potential (CRIG, 2010).

For many farmers, lack of resources including money and labor to apply the technologies, and technical difficulties were the key reasons for the low adoption of the technologies. To address the problem, the Government of Ghana for the past decade has intervened with the national Cocoa Diseases and Pests Control Program (CODAPEC) for mass spraying of cocoa farms, and the Cocoa High Technology Program (Hi-tech) which provides free inputs and labor for the control of capsids and black pod (Aneani, Anchirinah, Owusu-Ansah, \& Asamoah, 2012). Admittedly, the inputs from the CODAPEC program were inadequate and farmers were expected to supplement it and as such, the program has not been successful as expected. Oddly, the interventions to address this problem were targeted more to production techniques until as recently as 2012, when the Ghana Cocoa Board started the idea of Farmer Business Schools (FBS) to improve the market orientation of cocoa farmers. The FBS focuses on the business and entrepreneurial skills development of smallholder cocoa farmers, with the aim of improving their market orientation and subsequently, their motivation to invest and apply improved techniques (FAO, 2011; GIZ, 2015). The FBS is expected to improve producer knowledge of markets and marketing to enhance farmers' capacity to engage with and benefit from such activities (FAO, 2011). Since the financial and marketing-related issues are critically important for improving their incomes, the FBS seeks and adopts new technologies for further improvement in farming livelihoods (GIZ, 2015).

The decisions on adoption of new technologies in agriculture are usually complex, involving both quantitative and qualitative objectives (social, sustainability, rural development, etc.). Fortuin, Batterink, and Omta (2007) have argued that market failures arising from information asymmetry can hamper the success of adoption of innovation. It is also argued that market orientation can lead to positive economic results for a business entity (Ellinger, Ketchen Jr, Hult, Elmadağ, \& Richey Jr, 2008). In this sense, farmers who want positive results are more likely to adopt technologies to improve quality and to satisfy their customers. For example, in Valencia a positive relationship between market orientation, adoption of innovation, and economic results was observed, supporting the view that market dynamism influences firms' results (Schwartz, 2006). The presence of crop productions with strong market orientation was found to have favured the dissemination and adoption of innovations and economic results in the region (Aldas-Manzano, Küster, \& Vila, 2005).

From the afore-understanding in the extant literature, the provision of technical production information is positive for cocoa production and productivity, but it must be supported by economic and market information for better adoption and economic results. This new orientation can help farmers to consider the market in their production decisions and activities in order to enhance profits (GIZ, 2015). Anecdotal attribution to the problem of the cocoa industry in Ghana is that the market orientation of cocoa farmers is low. Blankson and David (2002) contended that market orientation principles have not been applied by many farmers because they perceive their farms as informal. Activities are mostly unplanned and rely on the intuition and energy of the farmer to make things happen. Thus, uptake of business and entrepreneurial ideas and technical innovations is limiting (Meziou, 1991).

Since 2012, the Ghana Cocoa Board in collaboration with GIZ (Deutsche Gesellschaft für Internationale Zusammenarbeit) has introduced the FBS with the aim of improving cocoa farmers' market orientation, to assist them in producing high-quality cocoa beans to attract premium prices from cocoa-buying companies and certification agencies for better incomes. Currently, however, there is limited empirical information to justify continued support of the FBS as tool for enhancing the market orientation of cocoa farmers. This study therefore seeks to ascertain the extent to which FBS can enhance market orientation among cocoa farmers in Ghana.

To address the research problem, the following specific objectives were set:

1. To ascertain the competency of cocoa farmers in terms of knowledge, skills, and attitude by comparing participants and non-participants of the FBS.

2. To determine the market orientation of cocoa farmers in terms of customer emphasis, competitor orientation, interfunctional coordination, intelligence generation, intelligence dissemination, and market responsiveness, by comparing participants and non-participants of the FBS.

\section{RESEARCH METHODOLOGY}

The study adopted a comparative survey research design with a focus on famers who have participated in the COCOBOD FBS since its inception and those who had yet to participate. The study was undertaken in the six cocoagrowing regions of Ghana. The study was comparative because the attribution of the competence acquired and market orientation gained through the FBS were on the basis of a comparison between participants and nonparticipants of the FBS. From an estimated 350,000 cocoa farmers in the study area, a sample of 600 respondents was taken representing the regions Ashanti (100 respondents), Brong Ahafo (100 respondents), Central (100 respondents), Eastern (100 respondents), Volta (60 respondents), and Western (140 respondents).

A multi-stage sampling technique was employed to select farmers. The census method was used in selecting the regions, i.e. all cocoa-growing regions in Ghana. The second stage involved the selection of cocoa-growing districts. Two districts from each of the regions, with the exception of Western (3) and Volta (1), making a total of 10 districts, were selected using the simple random sampling technique. This was done because Western had a very large population while Volta had the lowest. Selection of communities followed for the third stage. From each district, three communities each were selected through the simple random sampling technique. The final stage involved simple random sampling and selection of the cocoa farmers from communities to make up the sample size of 600 : 370 participants and 230 non-participants. In each of the simple random sampling techniques used, the balloting method 
was utilized whereby a list of subjects was produced (with information from COCOBOD), and researchers were blindfolded and selected the required numbers needed. This ensured that all subjects had an equal and independent chance of selection.

The research instrument (questionnaire) was designed to reflect the domain or key variables of the study competence in terms of knowledge (17 items), skills (17 items), and attitude (17 items), and market orientation in terms of customer emphasis (8 items), competitor orientation (8 items), interfunctional coordination (8 items), intelligence generation ( 8 items), intelligence dissemination ( 8 items), and market responsiveness ( 8 items). All items were derived from the literature and modified for use in this particular study (e.g. Dawes, 2000; Jaworski \& Kohli, 1993; Narver \& Slater, 1998). Data were collected using the questionnaire for both participants and non-participants of the FBS, and were analysed using mainly descriptive statistics (means and standard deviations). The results are presented in composite form in terms of the domain variables.

\section{RESULTS AND DISCUSSION}

\subsection{Competency of Cocoa Farmers}

3.1.1. Knowledge of Cocoa Farmers

Table 1 explains the mean knowledge of cocoa farmers acquired in the FBS and that of the non-participants. The lowest knowledge score observed for participant cocoa farmers concerned being familiar with profit and loss analysis. This recorded a mean of 2.50 and a standard deviation of 0.94 . Accordingly, cocoa farmers are classified as inefficient. Efficient farm managers want to be able to determine the position of their business at any point of time. The breakeven point and expected profit are very important analyses done by farm producers who want to know how much they have to produce to cover costs and make profits thereafter. The profit and loss analysis involved classifying and allocating to the products and or activities of the farm business, and making it easy to measure profitability (Wernerfelt, 1984).

Table-1. Knowledge of cocoa farmers (participants and non-participants).

\begin{tabular}{|c|c|c|}
\hline \multirow[t]{2}{*}{ Knowledge } & Participants & Non-participants \\
\hline & Mean (std. dev.) & Mean (std. dev.) \\
\hline a. I am familiar with profit and loss analysis & $2.50(0.94)$ & $2.99(0.99)$ \\
\hline $\begin{array}{l}\text { b. I can differentiate between commercial agriculture and other } \\
\text { businesses }\end{array}$ & $4.19(0.78)$ & $2.80(1.23)$ \\
\hline c. I understand the cocoa financial calendar & $3.55(1.09)$ & $2.81(1.19)$ \\
\hline d. I know the ways to improve my cocoa production & $3.99(0.79)$ & $3.13(1.08)$ \\
\hline e. I know the criteria used for selecting quality cocoa & $4.08(0.81)$ & $3.54(1.01)$ \\
\hline $\begin{array}{l}\text { f. I know the conditions involved in dealing with financial } \\
\text { service providers }\end{array}$ & $4.14(0.88)$ & $2.62(1.18)$ \\
\hline g. I know the obligations of membership in FBO & $4.15(0.73)$ & $3.17(1.05)$ \\
\hline h. I know the benefits of collective business actions & $4.19(0.76)$ & $2.76(1.18)$ \\
\hline i. I know the importance of savings & $4.27(0.81)$ & $4.10(0.85)$ \\
\hline j. I know the factors that make farmer organizations succeed & $4.31(0.46)$ & $2.53(1.25)$ \\
\hline k. I know the investment needs of my farm business & $4.32(0.47)$ & $2.75(1.21)$ \\
\hline 1. I know the benefits of reimbursing credits & $4.35(0.63)$ & $3.65(1.14)$ \\
\hline m. I know the importance of farm credit & $4.38(0.75)$ & $4.19(0.88)$ \\
\hline
\end{tabular}

Note: Scale: 1, no knowledge; 2, very low; 3, low; 4, high; 5 , very high.

In Table 1 the lowest score for non-participant cocoa farmers concerned knowing the factors that make farmer organizations succeed. This recorded a mean of 2.53 and a standard deviation of 1.25. Accordingly, the most obvious explanation is that they were not trained. It could also be that they had either never been part of farmer organizations or, if they had, they did not realize any benefit from their participation. However, Paladino (2008) indicated that farmer-based organizations aim to secure economic, social, and wider benefits to farmers through expanding their social capital and building the capacity of local communities. Farmer organizations also enhance the ability of smallholders to improve productivity and product quality and to access market information and inputs, while small-scale farmers save money to accumulate capital and collectively run economic activities. Farmers extend networks and experience stronger social cohesion and relationships through collective work. Farmers' participation in farmer organizations helps them to gain management skills as well as experience in conflict resolution and public speaking. Overall, it increases their capability and self-confidence to articulate their interests.

In a study in China, Zhou, Gao, Yang, and Zhou (2005) enumerated the factors that make farmer organizations succeed. They mentioned factors such as a stable legal environment, government support, a dedicated initiator, farmers' understanding of and participation in cooperative activities, transparent and efficient internal management, product orientation, cooperative and technical training, and appropriate external support from professional NGOs.

The highest knowledge score for cocoa farmers (both participants and non-participants) was their ability to know the importance of farm credit. This recorded a mean of 4.38 and a standard deviation of 0.75 for participants and a mean of 4.19 and a standard deviation of 0.88 for non-participants, suggesting that the cocoa farmers were well versed in credit issues since they knew the importance of farm credit. The reason for this, as explained by Ghorbani (2005), could be that most farmers perceive credit accessibility as important for the improvement of quality and 
quantity of farm products, and also it can help increase their income. Therefore, with the robustness required for cocoa businesses, farmers will be very interested in farm credit because they know how it can help improve their business.

\subsubsection{Skills of Cocoa Farmers}

Table 2 explains the mean skills of cocoa farmers acquired in the FBS and those of non-participants. The lowest skill observed for participant cocoa farmers was filling the simple cropping calendar. This recorded a mean of 4.11 and a standard deviation of 1.23. Although the mean value was high, it was the lowest in comparison with all the other skills acquired during the FBS. The lowest skill observed for non-participant cocoa farmers was using the financial calendar to plan farm/household expenditure. This recorded a mean of 1.83 and a standard deviation of 0.89 . The results found here confirm the findings of Akoto (2015), who observed that, generally, most cocoa farmers have low skills in areas such as farm planning, calculating business profits, practice of savings, credit worthiness, loan cosign consequences, insurance practice, and financial investments. Other areas such as record keeping remain a gray area for most farmers, although it has the potential to reduce risks significantly.

The highest skill observed for both participant and non-participant cocoa farmers was producing good-quality cocoa following COCOBOD techniques. This recorded a mean of 4.36 and standard deviation of 0.83 (participants) and a mean of 4.16 and standard deviation of 0.93 for non-participants. The implication for this result is that cocoa farmers are highly skilled in producing good-quality cocoa following COCOBOD techniques.

Table-2. Skills of cocoa farmers (participants and non-participants).

\begin{tabular}{|c|c|c|}
\hline \multirow[t]{2}{*}{ Skills } & Participants & Non-participants \\
\hline & Mean (std. dev.) & Mean (std. dev.) \\
\hline a. Fill a simple cropping calendar & $4.11(1.23)$ & $1.94(1.06)$ \\
\hline b. Obtain a guarantee for a loan & $4.14(1.14)$ & $2.80(1.33)$ \\
\hline c. Manage financial deficits and surplus money & $4.15(1.12)$ & $2.81(1.06)$ \\
\hline $\begin{array}{l}\text { d. Use the financial calendar to plan my farm/household } \\
\text { expenditure }\end{array}$ & $4.16(1.14)$ & $1.83(0.89)$ \\
\hline e. Determine profit or loss of my farm business & $4.18(1.14)$ & $2.76(1.23)$ \\
\hline f. Calculate money out and money in & $4.19(1.15)$ & $2.29(1.33)$ \\
\hline g. Bargaining new farm opportunities & $4.19(1.09)$ & $2.77(1.32)$ \\
\hline h. Manage savings and reimburse a loan & $4.21(1.1)$ & $2.64(1.24)$ \\
\hline i. Assess a cooperative business opportunity & $4.22(1.07)$ & $2.84(1.40)$ \\
\hline j. Measure a plot with simple tools & $4.24(1.12)$ & $2.05(1.02)$ \\
\hline k. Contribute to strengthen FBO in business & $4.25(1.02)$ & $3.55(1.23)$ \\
\hline 1. How to access cocoa farm support services & $4.28(1.01)$ & $3.16(1.06)$ \\
\hline $\begin{array}{l}\text { m. Produce good-quality cocoa following } \\
\text { techniques }\end{array}$ & $4.36(0.83)$ & $4.16(0.93)$ \\
\hline
\end{tabular}

Note: Scale: 1, no knowledge; 2, very low; 3 , low; 4, high; 5 , very high.

\subsubsection{Attitudes of Cocoa Farmers}

Table 3 explains the attitude of cocoa farmers towards the FBS and that of non-participants. Investigation into the attitudes of cocoa farmers towards the FBS was prompted by the general perception that their attitudes stand in the way of efforts to achieve higher cocoa productivity. Many workers in the cocoa sector posit that cocoa cultivation in Ghana will move forward if farmers are encouraged to change their attitude towards cocoa as a business enterprise (Baah, Anchirinah, \& Amon-Armah, 2011). The lowest attitude developed for participant cocoa farmers was "recording of money inflows/outflows helps in managing my money" and "diversifying to manage risks"; this was observed among $41 \%$ of respondents. Among non-participants, the lowest attitude developed was on saving money for future needs; this was observed among $18 \%$ of respondents. The implication is that the majority of participants do not perceive that recording their money inflows/outflows helps in managing their money and that diversification helps them to manage risks; for non-participants, they do not perceive saving their money for future needs as a good attitude.

The highest attitude developed by both participant and non-participant cocoa farmers was seeing their farm as a business. This was observed among 73 and $64 \%$ of respondents, respectively. The implication is that majority of cocoa farmers perceive their farm as a business. This is the right mentality expected of every cocoa farmer who intends to improve his or her income and livelihood. Osei-Bonsu, Baah, and Afrifa (2001) also confirmed that farmers' objectives include the meeting of the subsistence needs of their families, the search for capital to invest elsewhere, provision of inheritable property to next of kin, and the use of cocoa as security for old age. Therefore, they will adopt any program that can help them fulfill this objective. The FBS was aimed at helping meet the needs of the cocoa farmers. If farmers hope to achieve these objectives, it is expected that they would hold favorable attitudes towards cocoa cultivation to be sufficiently motivated to work towards their goals. 
Table-3. Attitudes of cocoa farmers (participants and non-Participants).

\begin{tabular}{l|c|c}
\hline \multirow{2}{*}{ Attitude } & Participants & Non-participants \\
\cline { 2 - 3 } & \% (agree) & \% (agree) \\
\hline $\begin{array}{l}\text { a. Recording of money inflows/outflows helps in } \\
\text { managing my money }\end{array}$ & 40.54 & 38.26 \\
\hline b. Diversification helps me to manage risks & 40.54 & 23.04 \\
\hline $\begin{array}{l}\text { c. I spend my money carefully } \\
\begin{array}{l}\text { d. Record keeping helps me to evaluate my } \\
\text { business }\end{array}\end{array}$ & 54.32 & 22.61 \\
\hline e. Collective action helps me to get better prices & 52.97 \\
\hline $\begin{array}{l}\text { f. I stick to my original objective of taking farm } \\
\text { credits }\end{array}$ & 54.04 & 19.57 \\
\hline $\begin{array}{l}\text { g. I play a key role in ensuring the quality of my } \\
\text { cocoa beans }\end{array}$ & 54.04 & 18.70 \\
\hline h. I save my money for future needs & 55.14 & 20.87 \\
\hline $\begin{array}{l}\text { i. Trust, transparency, and solidarity are needed } \\
\text { for governance of FBO }\end{array}$ & 62.70 & 18.26 \\
\hline j. I see replanting/planting as an investment & 63.51 & 55.65 \\
\hline $\begin{array}{l}\text { k. Standard plot measurements are used for farm } \\
\text { negotiations }\end{array}$ & 63.51 & 23.48 \\
\hline l. I see myself as an entrepreneur & 69.92 & 33.48 \\
\hline \begin{tabular}{l} 
m. I see my farm as a business \\
\hline
\end{tabular} & 73.24 & 33.91 \\
\hline
\end{tabular}

\subsubsection{Summary of Competency Indicators}

Participants in the FBS had a higher knowledge (mean $=4.07)$ than non-participants $($ mean $=3.12)$. The results showed that a greater proportion of participants had a positive attitude (56\%) than non-participants (31\%). Participants of the FBS had higher skills $($ mean $=4.21)$ than non-participants $($ mean $=2.74)$.

Table-4. Summary of competency indicators.

\begin{tabular}{l|c|c}
\hline Competency in FBS & Participants & Non-participants \\
\hline Knowledge (mean/std. dev.)* & $4.07(0.34)$ & $3.12(0.49)$ \\
\hline Skills (mean/std. dev.)** & $4.21(0.75)$ & $2.74(0.59)$ \\
\hline Attitude (\%) *** & 55.93 & 30.87 \\
\hline
\end{tabular}

Measurement: * Scale: 1, no knowledge; 2, very low; 3, low; 4, high; 5, very high.

** Scale: 1 , no skill; 2 , very low; 3 , low; 4 , high; 5 , very high.

*** Scale: $<50 \%$, negative; $>50 \%$, positive.

Table 4 gives a descriptive statistical summary of the competency indicators - knowledge, attitude, and skills of cocoa farmers (participants and non-participants). The reason for the higher knowledge, positive attitude, and better skills among participants compared to non-participants could be the greater exposure that the former had in the FBS module. The FBS as a training program was also aimed at improving the knowledge of cocoa farmers, changing their attitudes towards cocoa farming, and improving their skills. At the FBS, participants were engaged in financial and entrepreneurial issues (profit and loss analysis, measurement of cocoa farms, dealing with financial service providers, improving cocoa production, quality criteria for cocoa selection, benefits of collective actions, savings, investments, farm credits, diversification, etc.). Therefore, it is very likely that those who participated in the FBS will be more knowledgeable, have a positive attitude, and be more skilful than those who did not participate.

A case that supports this assertion is a piloted finance and social literacy program, organized by Unilever Ghana in partnership with Solidaridad, with young cocoa farmers in Ghana to encourage them to work in the sector. In that study, it was found that about $99 \%$ of participants in the program experienced high knowledge in the training models on business and financial literacy issues compared to those who did not participate. In terms of skills, about $68 \%$ of participants gained better skills compared to $25 \%$ of non-participants (Unilever, 2017). This supports the claim that cocoa farmers who participate in finance or business-related programs are more likely to experience improvement in knowledge, attitude, and skills than those who do not participate or are yet to participate.

\subsection{Market Orientation of Cocoa Farmers \\ 3.2.1. Customer Emphasis}

Table 5 explains the customer emphasis of cocoa farmers. The lowest score on customer emphasis for participants was on how they treat LBCs as business partners (mean $=2.51$ ) while for non-participants it was on how they look for ways to satisfy the needs of their LBCs $($ meanm $=\mathrm{m} 2.45)$. This means that most of the participants do not treat LBCs as business partners, and also for the non-participants, most of whom do not look for ways to satisfy the needs of the LBCs. Cocoa farmers in Ghana are fixed in a "straightjacket". This is because there is no flexibility in terms of who their customers are. It is only the LBCs who have been licenced by COCOBOD to purchase their cocoa beans. With a monopolized marketing arrangement, cocoa farmers are not likely to do anything extra in order to benefit from their partnership with the LBCs. This may account for the reason why they do not look for ways to satisfy the needs of the LBCs and they do not treat them as their business partners. The result is that they may be 
able to achieve very little through their level of customer emphasis (Narver \& Slater, 1998). Again, the only change that could occur is that there are different groups of LBCs that farmers can probably treat as different customers. Beyond that, cocoa farmers are tied to only one customer. A market-oriented cocoa farmer may be more aware and be exposed to different buyers (not only LBCs) and exploit that arrangement for their benefit.

The highest score on customer emphasis for both participants (mean $=4.48)$ and non-participants $($ mean $=4.54)$ was on knowing the quality criteria used by LBCs in purchasing. The implication is that the majority of cocoa farmers know the quality criteria used by LBCs in purchasing their cocoa beans. Jaworski and Kohli (1993) indicated that customer emphasis is not only about meeting the needs of the immediate consumer, but seeing the wider picture and providing products that meet the needs of immediate buyers and buyers' buyers. This could account for the reason why cocoa farmers know the quality criteria used by the LBCs in purchasing their cocoa.

Table-5. Customer emphasis.

\begin{tabular}{l|c|c}
\hline Customer emphasis & Participants & Non-participants \\
\cline { 2 - 3 } & Mean (std. dev.) & Mean (std. dev.) \\
\hline a. I treat LBCs as business partners & $2.51(0.78)$ & $2.47(1.05)$ \\
\hline b. I consult LBCs to improve my activities with them & $2.81(0.97)$ & $2.45(1.05)$ \\
\hline c. I encourage LBC comments and complaints & $2.87(0.94)$ & $2.84(1.24)$ \\
\hline d. I incorporate LBC comments into farm operations & $2.54(0.21)$ & $3.02(1.62)$ \\
\hline e. I look for ways to satisfy the needs of the LBCs & $3.07(0.91)$ & $2.45(1.06)$ \\
\hline f. I know the quality criteria used by LBCs in purchasing & $4.48(0.65)$ & $4.54(0.65)$ \\
\hline
\end{tabular}

Note: Scale: very low, 1 ; low, 2 ; moderate, 3 ; high, 4 ; very high, 5 .

Key: LBC, Licensed buying companies.

\subsubsection{Competitor Orientation}

Table 6 explains the competitor orientation of cocoa farmers. The lowest score on competitor orientation for participants was on monitoring LBCs buying from other farmers (mean $=2.07$ ) while for non-participants it was knowing whether LBCs buying from other farmers were satisfied (mean $=1.97$ ). This means that most participants do not monitor LBCs buying from other farmers, and likewise for most non-participants, they do not know whether LBCs buying from other farmers are satisfied. The low level of competitor orientation is that, generally, most cocoa farmers do not perceive their fellow cocoa farmers as their competitors. They all sell to the same customer and they receive the same unit returns from their sales. They therefore do not focus on how their competitors (fellow cocoa farmers) are devising policies to satisfy the needs of their customers (LBCs) (Ellis, 2006). There is no point in devising strategies to gain competitive advantage over other farmers if the end point (market) is fixed. The orientation for competition among cocoa farmers could be changed and improved if markets or customers and the unit returns are diverse. However, with the current arrangement where only the LBCs are licenced to purchase cocoa beans from the cocoa farmers, and at fixed prices, competition among cocoa farmers may still remain low.

The highest score on competitor orientation for participants was on knowing whether LBCs buying from other farmers are satisfied (mean $=2.18$ ), while for non-participants it was on monitoring LBCs buying from other farmers $($ mean $=2.02)$. This means that most participants know whether LBCs buying from other farmers are satisfied while most non-participants monitor LBCs buying from other farmers. Aziz and Yasin (2010) noted that within the local cocoa farming system, farmers are also aware that their fellow farmers do other things that get them better value and other benefits from LBCs. This could be another form of competition. They could devise a good understanding of the changing behaviors of their fellow cocoa farmers who are their current and future competitors. When this is done, they will be able to make greater profits, since Dawes (2000) asserted that the competitor orientation component of market orientation is positively correlated to company profitability. Without it, cocoa farmers will always have low levels of profitability.

Table-6. Competitor orientation.

\begin{tabular}{|c|c|c|}
\hline \multirow[t]{2}{*}{ Competitor orientation } & Participants & Non-participants \\
\hline & Mean (std. dev.) & Mean (std. dev.) \\
\hline a. I monitor LBCs buying from other farmers & $2.07(0.59)$ & $2.02(0.66)$ \\
\hline b. I know whether other farmers are open to LBC complaints & $2.09(0.60)$ & $1.90(0.70)$ \\
\hline c. I know whether other farmers meet LBC quality criteria & $2.14(0.59)$ & $1.99(0.77)$ \\
\hline d. I know whether LBCs buying from other farmers are satisfied & $2.18(0.62)$ & $1.97(0.69)$ \\
\hline
\end{tabular}

Note: Scale: very low, 1; low, 2; moderate, 3 ; high, 4; very high, 5 .

Key: LBC, Licensed buying companies.

\subsubsection{Interfunctional Coordination}

Table 7 explains the interfunctional coordination of cocoa farmers. The lowest score on interfunctional coordination for both participants (mean $=1.99$ ) and non-participants (mean $=1.96$ ) was on coordinating activities aimed at training farm workers. This means that most cocoa farmers are not interested in training their farm workers. Generally, farming in Ghana is not perceived as a business entity that requires the setting up of different departments and functions. However, as defined by Zhou, Brown, and Dev (2009), interfunctional coordination could be viewed as the coordination of farm resources and customer-related activities. Cocoa farmers are therefore expected 
to also develop a mechanism to coordinate activities with their workers, extension agents, licenced buying companies, input suppliers, and others for the growth of their business. According to Amalia, Ionu, and Cristian (2008), cocoa farmers who are able to do this will be able to create and deliver superior value to their customers and obtain sustainable competitive advantage.

The highest score on interfunctional coordination for both participants (mean $=4.10$ ) and non-participants $($ mean $=3.98)$ was on having a cordial working relationship with key actors (mean $=4.10$, mean $=3.98$, respectively). This means that the majority of cocoa farmers have a cordial working relationship with key actors.

Table-7. Interfunctional coordination

\begin{tabular}{|c|c|c|}
\hline \multirow[t]{2}{*}{ Interfunctional coordination } & Participants & Non-participants \\
\hline & Mean (std. dev.) & Mean (std. dev.) \\
\hline a. I coordinate activities aimed at training my farm workers & $1.99(0.80)$ & $1.96(1.09)$ \\
\hline $\begin{array}{l}\text { b. I coordinate meetings to discuss market trends with key } \\
\text { actors }\end{array}$ & $2.12(0.61)$ & $2.00(0.67)$ \\
\hline c. I discuss the future needs of my farm with key actors & $2.62(0.92)$ & $2.57(1.03)$ \\
\hline d. I have a cordial working relationship with key actors & $4.10(0.71)$ & $3.98(0.98)$ \\
\hline
\end{tabular}

\subsubsection{Intelligence Generation}

Table 8 explains the intelligence generation of cocoa farmers. The lowest score on intelligence generation for both participants $($ mean $=1.91)$ and non-participants $($ mean $=2.10)$ was searching for information on cocoa market trends. This means that most participants and non-participants do not search for information on cocoa market trends. For cocoa farmers to serve the market better than their competitors, information regarding existing and perceived future needs and wants of customers needs to be collected (Zebal \& Goodwin, 2012). This is done through the act of intelligence gathering. According to Lafferty and Hult (2001), intelligence generation is a unifying element that defines market orientation. Therefore, with a low level of intelligence gathering, it means that cocoa farmers are not aggressive in information or intelligence generation regarding their buyers and competitors and the other factors that affect their purchasing. This means that they cannot experience novelty and meaningfulness in producing new valued options that align with customer expectations (Ho \& Tsai, 2006).

The highest score on intelligence generation for both participants (mean $=2.79$ ) and non-participants $($ mean $=$ 3.04) was on assessing LBC perception on the quality of their cocoa beans. This means that most cocoa farmers assess LBC perception on the quality of their cocoa beans.

Table-8. Intelligence generation.

\begin{tabular}{l|c|c}
\hline Intelligence generation & Participants & Non-participants \\
\cline { 2 - 3 } & Mean (std. dev.) & Mean (std. dev.) \\
\hline $\begin{array}{l}\text { a. I search for information on cocoa market trends } \\
\text { b. I meet with LBCs to find out their future needs }\end{array}$ & $2.91(0.79)$ & $2.10(1.36)$ \\
\hline $\begin{array}{l}\text { c. I attend extension meetings to get information on new } \\
\text { cocoa technologies }\end{array}$ & $2.69(1.03)$ & $2.73(1.35)$ \\
\hline $\begin{array}{l}\text { d. I quickly detect changes in my farm operations } \\
\begin{array}{l}\text { e. I assess LBC perception on the quality of my cocoa } \\
\text { beans }\end{array}\end{array}$ & $2.70(0.95)$ \\
\hline
\end{tabular}

Note: Scale: very low, 1 ; low, 2 ; moderate, 3 ; high, 4 ; very high, 5 .

Key: LBC, Licensed buying companies.

\subsubsection{Intelligence Dissemination}

Table 9 explains the intelligence dissemination of cocoa farmers. The lowest score on intelligence dissemination for participants was on informing their workers when they find out something about other farmers $($ mean $=2.69)$ while for non-participants it was about informing their workers about their activities with LBCs $($ mean $=2.66)$. This means that most participants do not inform their workers when they find out something about other farmers, while most non-participants do not inform their workers about their activities with LBCs. It is expected that cocoa farmers disseminate the information they generate to all levels of their farm business. If this is done, the information is likely to affect their activities, the activities of their workers, and their relationship with other cocoa stakeholders. However, with a low level in intelligence dissemination, it means that they do not disseminate the information they are able to generate. The information generated and disseminated by cocoa farmers should go beyond simply customer satisfaction into satisfying other key areas of the cocoa farm business (Narver \& Slater, 1998).

The highest score on intelligence dissemination for participants was informing their workers about their activities with LBCs (mean = 2.78) while for non-participants it was about informing their workers when they find out something about other farmers (mean $=2.99$ ). This means that most participants inform their workers about their activities with LBCs while most non-participants inform their workers when they find out something about other farmers. As cocoa farmers are able to disseminate the information they generate to all levels of their farm business, the information is likely to affect their activities, the activities of their workers, and their relationship with other cocoa stakeholders (Narver \& Slater, 1998). 
Table-9. Intelligence dissemination.

\begin{tabular}{l|c|c}
\hline Intelligence dissemination & Participants & \multicolumn{1}{c}{ Non-participants } \\
\cline { 2 - 3 } & Mean (std. dev.) & Mean (std. dev.) \\
\hline $\begin{array}{l}\text { a. I inform LBCs on issues relevant to their relationship with } \\
\text { me }\end{array}$ & $2.58(1.03)$ & $2.67(1.35)$ \\
\hline $\begin{array}{l}\text { b. When I find out something about other farmers, I inform } \\
\text { my workers }\end{array}$ & $2.69(1.04)$ \\
\hline $\begin{array}{l}\text { c. Information on LBC satisfaction is disseminated to all } \\
\text { workers }\end{array}$ & $2.71(1.07)$ & $2.83(1.31)$ \\
\hline \begin{tabular}{l} 
d. I inform LBCs on issues affecting my farm operations \\
\hline e. I inform my workers about my activities with LBCs
\end{tabular} & $2.73(1.07)$ & $2.78(1.03)$ \\
\hline
\end{tabular}

Note: Scale: very low, 1; low, 2; moderate, 3; high, 4; very high, 5 .

Key: LBC, Licensed buying companies.

Source: Field survey.

\subsubsection{Market Responsiveness}

Table 10 explains the market responsiveness of cocoa farmers. The lowest score on market responsiveness for both participants $($ mean $=1.68)$ and non-participants $($ mean $=1.91)$ was making new offers based on world market prices of cocoa. This means that most participants and non-participants do not make new offers based on world market prices of cocoa. The implication is that cocoa farmers are not responsive to the market. They do not make new offers based on world market prices of cocoa, they do not choose the best purchasing packages from the LBCs, and they do not come up with any new business strategy and implement it in timely fashion.

Under the current marketing arrangement with COCOBOD, it is not unexpected that cocoa farmers are not market responsive. Changes in world market prices do not affect the returns they get from the sale of their cocoa beans. They are given a fixed price, whether there is a rise or a fall in the world market price. However, the LBCs have developed various strategies and packages in order to attract cocoa farmers. These packages include giving loans and supplying farm inputs and training activities, but not in the area of cocoa prices. Depending on LBC packages, cocoa farmers can make their own choices.

The highest score on market responsiveness for both participants $($ mean $=3.18)$ and non-participants $($ mean $=$ 3.57) was venturing into other business opportunities as back-up in the minor season. This means that most participants and non-participants venture into other business opportunities as back up in the minor season. They ensure that their new business opportunities do not conflict with their work as cocoa farmers and they venture into other business opportunities as back up in the minor season. The implication is that if cocoa farmers become market responsive, they can have a competitive advantage in both the speed and effectiveness of their reaction to intelligence generated and disseminated (Chen \& Volpe, 2002).

Table-10. Market responsiveness.

\begin{tabular}{|c|c|c|}
\hline \multirow[t]{2}{*}{ Market responsiveness } & Participants & Non-participants \\
\hline & Mean (std. dev.) & Mean (std. dev.) \\
\hline $\begin{array}{l}\text { a. I make new offers based on world market prices of } \\
\text { cocoa }\end{array}$ & $1.68(0.73)$ & $1.91(1.09)$ \\
\hline b. I choose the best purchasing packages from the LBCs & $2.65(1.05)$ & $2.64(1.31)$ \\
\hline $\begin{array}{l}\text { c. When I come up with any new business strategy, it is } \\
\text { implemented in timely fashion }\end{array}$ & $2.79(1.02)$ & $2.79(1.12)$ \\
\hline $\begin{array}{l}\text { d. I ensure my new business opportunities do not conflict } \\
\text { with my work as a cocoa farmer }\end{array}$ & $2.97(0.84)$ & $3.17(0.99)$ \\
\hline $\begin{array}{l}\text { e. I venture into other business opportunities as back up in } \\
\text { the minor season }\end{array}$ & $3.18(1.08)$ & $3.57(1.19)$ \\
\hline
\end{tabular}

Note: Scale: very low, 1; low, 2; moderate, 3; high, 4; very high, 5 .

Key: LBC, Licensed buying companies.

Table-11. Market orientation indicators.

\begin{tabular}{l|c|c}
\hline \multirow{2}{*}{ Indicator } & Pable-11. Market orientation indicators. \\
\cline { 2 - 3 } & Mean (std. dev.) & Non-participants \\
\hline Competitor orientation & $2.12(0.42)$ & $1.97(0.57)$ \\
\hline Intelligence generation & $2.55(0.58)$ & $2.68(0.98)$ \\
\hline Market responsiveness & $2.66(0.47)$ & $2.82(0.71)$ \\
\hline Intelligence dissemination & $2.69(0.78)$ & $2.77(1.12)$ \\
\hline Interfunctional coordination & $2.71(0.42)$ & $2.63(0.49)$ \\
\hline Customer emphasis & $3.05(0.51)$ & $2.96(0.67)$ \\
\hline Overall market orientation & $2.63(0.35)$ & $2.56(0.50)$ \\
\hline Standard error of means & 0.02 & 0.03 \\
\hline
\end{tabular}

Note: Scale: very low, 1; low, 2; moderate, 3 ; high, 4; very high, 5. 


\subsubsection{Summary of Market Orientation Indicators}

Participants in the FBS (2.12) are more competitor oriented than non-participants (1.97); participants (2.55) have less intelligence generation than non-participants (2.68); participants (2.66) are less market responsive than nonparticipants (2.82); participants (2.69) have less intelligence dissemination than non-participants (2.77); participants (3.05) have more customer emphasis than non-participants (2.96); and participants (2.71) have more interfunctional coordination than non-participants (2.63).

Table 11 is a mean and standard deviation summary of the market orientation indicators. The findings also suggest than while the participants in the FBS have higher scores for customer emphasis, competitor orientation, and interfunctional coordination than non-participants, the latter have higher scores for intelligence generation, intelligence dissemination, and market responsiveness. The things taught at the FBS could have given the participants a new orientation in terms of customer emphasis, competitor orientation, and interfunctional coordination. For non-participants, they may have shown greater aggression than participants in trying to generate and disseminate their own intelligence while trying to be more responsive to the market.

With competitor orientation as the lowest indicator in the market orientation of cocoa farmers (both participants and non-participants), this means that cocoa farmers do not have an understanding of their competitors' strengths or strategies. The case is that cocoa farmers do not even perceive their fellow cocoa farmers as their competitors. A good competitor orientation could help cocoa farmers to recognize the quality and quantity of cocoa bean s to produce and the LBCs markets to enter/avoid (Adjei-Ababio, 2011). With customer emphasis as the highest indicator in the market orientation of cocoa farmers (both participants and non-participants), cocoa farmers will be able to achieve more through their customer emphasis in relation to the LBCs (Narver \& Slater, 1998). However, this must not simply be about meeting the needs of the immediate consumer (LBCs) but seeing the wider picture and providing products that meet the needs of immediate buyers and buyers' buyers (Jaworski \& Kohli, 1993).

In comparing the overall market orientation of FBS participants and non-participants, a marginal difference will be noted. The evidence still exists that participants have a higher market orientation than non-participants.

\section{CONCLUSION}

The FBS as an extension approach has made significant incursions into the Ghanaian cocoa sector. Areas of the knowledge, attitude, and skills of cocoa farmers have been improved or enhanced. From the study findings, it was realised that participants of the FBS had a greater knowledge than non-participants. A higher proportion of participants had a positive attitude than non-participants; participants had better skills than non-participants. In the area of market orientation, areas such as competitor orientation, customer emphasi,s and interfunctional coordination have seen some level of improvement among cocoa farmers. These areas in times past were not of interest to cocoa farmers but, however, through the FBS, the same can no longer be said. The study found that FBS participants were more competitor oriented than non-participants, had less intelligence generation, were less market responsive, had less intelligence dissemination, had more customer emphasis, and had more interfunctional coordination. Based on these conclusions, the study recommends the scaling up of the program since not all cocoa-growing communities are currently benefiting from the FBS. Also, the market orientation of cocoa farmers can be enhanced by the provision of relevant practical experience for attitudinal change.

Funding: This study received no specific financial support.
Competing Interests: The authors declare that they have no competing interests.
Contributors/Acknowledgement: All authors contributed equally to the conception and
design of the study.
Views and opinions expressed in this study are those of the authors views; the Asian Journal of
Agriculture and Rural Development shall not be responsible or answerable for any loss, damage,
or liability, etc. caused in relation to/arising out of the use of the content.

\section{REFERENCES}

Adjei-Ababio, K. (2011). Evaluation of competitive strategies of the Licensed Cocoa Buying Companies (LBCs) in Ghana: A case study of Produce Buying Company Ltd. Kwame Nkrumah University of Science and Technology, Kumasi.

Akoto, G. O. (2015). An analysis of personal financial literacy among cocoa farmers in Ghana. Kwame Nkrumah University of Science and Technology, KNUST-Kumasi.

Aldas-Manzano, J., Küster, I., \& Vila, N. (2005). Market orientation and innovation: An inter- relationship analysis. European Journal of Innovation, 8(4), 437-452. Available at: https://doi.org/10.1 108/14601060510627812.

Amalia, P., Ionu, P., \& Cristian, N. (2008). Market orientation: An interdisciplinary and complex concept. The Journal of the Faculty of Economics, $17(4), 1055-1059$.

Aneani, F., Anchirinah, V. M., Owusu-Ansah, F., \& Asamoah, M. (2012). Adoption of some cocoa production technologies by cocoa farmers in Ghana. Sustainable Agriculture Research, 1(1), 103-1 17. Available at: https://doi.org/10.5539/sar.v1n 1p103.

Aziz, N. A., \& Yasin, N. M. (2010). How will market orientation and external environment influence the performance among SMEs in the agri-food sector in Malaysia? International Business Research, 3(3), 154. Available at: https://doi.org/10.5539/ibr.v3n3p 154.

Baah, F., Anchirinah, V., \& Amon-Armah, F. (2011). Soil fertility management practices of cocoa farmers in the Eastern Region of Ghana. Agriculture and Biology Journal of North America, 2(1), 2151-7517. Available at: https://doi.org/10.5251/abjna.2011.2.1.173.181.

Blankson, C., \& David, S. (2002). Marketing practices in the UK small business sector. Marketing Intelligence E Planning, 20(1), 4961. Available at: https://doi.org/10.1108/02634500210414774. 
Chen, H., \& Volpe, P. R. (2002). Gender differences in personal financial literacy among college students. Financial Services Review, $11(3), 289-307$.

CRIG. (2010). Cocoa manual: Source book of sustainable cocoa production. Tafo, Ghana: Cocoa Research Institute of Ghana.

Dawes, J. (2000). Market orientation and company profitability: Further evidence incorporating longitudinal data. Australian Journal of Management, 25(2), 173-199. Available at: https://doi.org/10.1177/031289620002500204.

Ellinger, A. E., Ketchen Jr, D. J., Hult, G. T. M., Elmadağ, A. B., \& Richey Jr, R. G. (2008). Market orientation, employee development practices, and performance in logistics service provider firms. Industrial Marketing Management, 37(4), 353366. Available at: https://doi.org/10.1016/j.indmarman.2007.01.002.

Ellis, P. D. (2006). Market orientation and performance: A meta-analysis and cross-national comparisons. Journal of Management Studies, 43(5), 1089-1 107. Available at: https://doi.org/10.1111/j.1467-6486.2006.00630.x.

FAO. (2011). Farm business school, training of farmers programme. South Asia: Rap Publication 2011/o6a, Food and Agriculture Organisation.

Fortuin, F. T. J. M., Batterink, M.-H., \& Omta, S. W. F. (2007). Key success factors of innovation in multinational agrifood prospector companies. International Food and Agribusiness Management Journal, 1O(4), 1-24.

Ghorbani, M. (2005). The role of credit institutions in rural investment development in agricultural sector. Proposed Research to Agricultural Planning and Economic Research Institute. Jihad-Agriculture Ministry of Iran.

GIZ. (2015). Experiences with the farmer business school (FBS) approach in Africa (pp. 16). Sector Network Rural Development Africa (SNRD), Working Group, Agribusiness and Food Security, German Cooperation Deutsche Zusammenarbeit, Germany.

Gockowski, J., Afari-Sefa, V., Sarpong, D., Osei-Asare, Y., \& Dziwornu, A. (2011). Increasing income of Ghanaian cocoa farmers: Is introduction of fine flavour cocoa viable alternative. Quarterly Journal of International Agriculture, 2(50), 175-200.

Ho, Y. C., \& Tsai, T. H. (2006). The impact of dynamic capabilities with market orientation and resource-based approaches on NPD project performance. Journal of American Academy of Business, 8(1), 215-228.

Jaworski, B. J., \& Kohli, A. K. (1993). Market orientation: Antecedents and consequences. Journal of Marketing, 57(3), 53-70. Available at: https://doi.org/10.2307/1251854.

Lafferty, B. A., \& Hult, G. T. M. (2001). A synthesis of contemporary market orientation perspectives. European Journal of Marketing, 35(1), 92-109. Available at: https://doi.org/10.1108/03090560110363364.

Meziou, F. (1991). Areas of strength and weakness in the adoption of the marketing concept by small manufacturing firms. Journal of Small Business Management, 29(4), 72-78.

Narver, J. C., \& Slater, S. F. (1998). The effect of a market orientation on business profitability. Journal of Marketing, 54(4), $20-35$. Available at: https://doi.org/10.2307/1251757.

Obuobisa-Darko, E. (2015). Credit access and adoption of cocoa research innovations in Ghana. Research on Humanities and Social Sciences, 5(12), 16-29.

Osei-Bonsu, K., Baah, F., \& Afrifa, A. A. (2001). Evaluation of cocoa conditions, problems and possible solutions in four farming communities surrounding the Kakum forest reserve, Central region, Ghana. Consulting Report for Conservation, International, Ghana. Tafo: Cocoa Research, Institute of Ghana.

Paladino, A. (2008). Analyzing the effects of market and resource orientations on innovative outcomes in times of turbulence. Journal of Product Innovation Management, 25(6), 577-592. Available at: https://doi.org/10.1111/j.15405885.2008.00323.x.

Röling, N. (2009). Pathways for impact: Scientists' different perspectives on agricultural innovation. International Journal of Agricultural Sustainability, 7(2), 83-94. Available at: https://doi.org/10.3763/ijas.2009.0043.

Schwartz, J. (2006). The five founding principles That drive innovation. The Financial Times Limited. May 25.

Unilever. (2017). Financial and social literacy for young cocoa farmers in Ghana. Retrieved from: https://www.unilever.com/sustainable-living/enhancing-livelihoods/inclusive-business/livelihoods-for-smallholderfarmers/creating-an-inclusive-supply-chain/financial-and-social-literacy-for-young-cocoa-farmers-in-ghana.html.

Wernerfelt, B. (1984). A resource-based view of the firm. Strategic Management Journal, 5(2), 171-180.

Wiredu, A., Mensah-Bonsu, A., Andah, E., \& Fosu, K. (2011). Hybrid cocoa and land productivity of cocoa farmers in Ashanti Region of Ghana. World Journal of Agricultural Sciences, 7(2), 172-178.

Zebal, M. A., \& Goodwin, D. R. (2012). Market orientation and performance in Private Universities. Marketing Intelligence Eं Planning, 30(3), 339-357.

Zhou, K. Z., Brown, J. R., \& Dev, C. S. (2009). Market orientation, competitive advantage, and performance: A demand-based perspective. Journal of Business Research, 62(11), 1063-1070. Available at: https://doi.org/10.1016/j.jbusres.2008.10.001.

Zhou, K. Z., Gao, G. Y., Yang, Z., \& Zhou, N. (2005). Developing strategic orientation in China: Antecedents and consequences of market and innovation orientations. Journal of Business Research, 58(8), 1049-1058. Available at: https://doi.org/10.1016/j.jbusres.2004.02.003. 